\title{
SIMPLIFYING CELIAC DISEASE PREDISPOSING HLA-DQ ALLELES DETERMINATION BY THE REAL TIME PCR METHOD
}

\author{
Nicole SELLESKI ${ }^{1,5}$, Lucas Malta ALMEIDA', 5, Fernanda Coutinho de ALMEIDA ${ }^{2,5}$, \\ Lenora GANDOLFI ${ }^{1,2,3,5}$, Riccardo PRATESI ${ }^{1,2,3,5}$ and Yanna Karla de Medeiros NÓBREGA $2,4,5$
}

\begin{abstract}
Background - Celiac disease is an autoimmune enteropathy triggered by the ingestion of gluten in genetically susceptible individuals. Genetic susceptibility is associated with two sets of alleles, $D Q A 1 * 05-D Q B 1 * 02$ and $D Q A 1 * 03-D Q B 1 * 03: 02$, which code for class II MHC DQ2 and DQ8 molecules, respectively. Approximately 90\%-95\% of celiac patients are HLA-DQ2 positive, and half of the remaining patients are HLA-DQ8 positive. In fact, during a celiac disease diagnostic workup, the absence of these specific DQA and DQB alleles has a near perfect negative predictive value. Objective - Improve the detection of celiac disease predisposing alleles by combining the simplicity and sensitivity of real-time PCR (qPCR) and melting curve analysis with the specificity of sequence-specific primers (SSP). Methods - Amplifications of sequence-specific primers for $D Q A 1 * 05$ (DQ2), DQB1*02 (DQ2), and $D Q A 1^{*} 03$ (DQ8) were performed by the real time PCR method to determine the presence of each allele in independent reactions. Primers for Human Growth Hormone were used as an internal control. A parallel PCR-SSP protocol was used as a reference method to validate our results. Results - Both techniques yielded equal results. From a total of 329 samples the presence of HLA predisposing alleles was determined in $187(56.8 \%)$. One hundred fourteen samples $(61 \%)$ were positive for a single allele, $68(36.3 \%)$ for two alleles, and only 5 (2.7\%) for three alleles. Conclusion - Results obtained by qPCR technique were highly reliable with no discordant results when compared with those obtained using PCR-SSP.
\end{abstract}

HEADINGS - Celiac disease. HLA-DQ antigens. Histocompatibility testing. Real-time polymerase chain reaction.

\section{INTRODUCTION}

Celiac disease (CD) is an autoimmune enteropathy triggered by the ingestion of gluten in genetically susceptible individuals ${ }^{(2)}$. Once thought to be a rare disease, $\mathrm{CD}$ diagnoses are increasing with current worldwide prevalence at $1 \%{ }^{(3)}$. Gluten, the primary component of wheat, rye and barley, is the environmental agent responsible for $\mathrm{CD}$. Gluten is difficult to digest because it is rich in proline amino acid residues that tend to be more resistant to gastric and pancreatic enzymatic action. When these long undigested protein fragments undergo deamidation by tissue transglutaminases they become potent immunogenic epitopes. In celiac patients, these gluten-derived peptides bind to Major Histocompatibility Complex [MHC, or Human Leukocyte Antigen (HLA)] Class II molecules eliciting immune stimulation of CD4 T-cells ${ }^{(1)}$.
Approximately $60 \%$ of the genetic susceptibility to $\mathrm{CD}$ is shared by an unknown number of non-HLA genes with each gene estimated to contribute only a small proportion to the total risk effect ${ }^{(10)}$; therefore, detection of a single non-HLA gene has a low positive gain in the diagnosis of $\mathrm{CD}$. However, two sets of alleles, $D Q A 1^{*} 05-D Q B 1^{*} 02$ and $D Q A 1^{*} 03$ - $D Q B 1^{*}$ 03:02, which code for class II MHC DQ2 and DQ8 molecules, respectively, are carried by approximately one-third of the general population and account for $40 \%$ of the genetic susceptibility to $\mathrm{CD}^{(6,9)}$. In fact, approximately $90 \%-95 \%$ of celiac patients are HLA-DQ2 positive, while half of the remaining patients are HLA-DQ8 positive ${ }^{(4,5)}$. In addition, during a CD diagnostic workup, the absence of these specific DQA and DQB alleles has a near perfect negative predictive value ${ }^{(10)}$.

Being able to quickly and efficiently determine

Declared conflict of interest of all authors: none

Disclosure of funding: no funding received

Graduate Program in Health Sciences, School of Health Sciences, ${ }^{2}$ Graduate Program in Medical Sciences, School of Medicine; ${ }^{3}$ Department of Pediatrics, School of Medicine; ${ }^{4}$ Department of Pharmaceutical Sciences, School of Health Sciences; ${ }^{5}$ Research Center for Celiac Disease, School of Medicine. Universidade de Brasilia (UnB), Campus Universitário Darcy Ribeiro, Brasília, DF, Brazil.

Correspondence: Prof. ${ }^{a}$ Yanna Karla de Medeiros Nóbrega. Faculdade de Ciências da Saúde, Departamento de Ciências Farmacêuticas. Campus Universitário Darcy Ribeiro - CEP: 70910-900 - Brasília, DF, Brasil. E-mail: yannanobrega@gmail.com 
the status of these DQA and DQB alleles in potential CD patients or risk populations (celiac disease patient's first degree relatives, people with related autoimmune diseases, among others) could dramatically aide in diagnostic workups. However, currently available methods for screening of HLA-associated alleles in CD patients, which include Sequence-Specific Oligonucleotide Probe Hybridization (SSOPH), PCR amplification with Sequence-Specific Primers (PCR-SSP), and Sequence-Base Typing (SBT), are expensive and time-consuming. The aim of this study is to simplify the detection of three of these alleles $\left(D Q A 1^{*} 03 ; D Q A 1^{*} 05\right.$; $D Q B 1^{*} 02$ ) by developing a real-time PCR (or quantitative PCR, qPCR) protocol with melting curve analysis using Sequence-Specific Primers (SSP) previously developed for PCR-SSP( ${ }^{(7)}$.

\section{METHODS}

The study complied with the principles of the latest Declaration of Helsinki (2008) and was approved by the Research Ethics Committee on Medical Sciences of the University of Brasilia, School of Medicine (protocol $n^{\circ}$ 132/2008).

DNA was extracted from newborn umbilical cord blood (UCB) collected immediately after birth into an EDTA-coated tube. All mothers had previously agreed to participate in the research. DNA extraction was performed using Illustra ${ }^{\mathrm{TM}}$ Blood genomic Prep Mini Spin kit (Healthcare, Buckinghamshire, UK) according to the manufacturer's instructions. Concentration of DNA samples were adjusted to $15 \mathrm{ng} / \mu \mathrm{L}$ after being quantified at Nanodrop ND-1000 Spectrophotometer (Nanodrop Technologies, Wilmington, DE, USA), which measures absorbance at $260 \mathrm{~nm}$ and $280 \mathrm{~nm}$. Samples were considered suitable for analyses when the ratio of absorbances (A260/A280) was between 1.8 and 2 .

Sequence-specific primers for $D Q A 1 * 05$ [(5'-ACGGTCCCTCTGGCCAGTA, 3'-AGTTGGAGCGTTTAATCAGAC) (DQ2)], DQB1*02 [(5'-GTGCGTCTTGTGAGCAGAAG, 3'-GCAAGGTCGTGCGGAGCT) (DQ2)], and $D Q A 1 * 03$ [(5'-TTCACTCGTCAGCTGACCAT, 3'-CAAATTGCGGGTCAAATCTTCT) (DQ8)] previously described by Olerup et al. (1993) ${ }^{(7)}$ were used to test for the presence of each allele in independent reactions. Primers for Human Growth Hormone (HGH) were used as an internal control ${ }^{(8)}$. Amplifications were performed on a StepOne Real-Time PCR System (Applied Biosystems-Life Technologies ${ }^{\mathrm{TM}}$, Carlsbad, CA, USA). For DQ alleles, amplifications were performed in $20 \mu \mathrm{L}$ volume containing $2 \mu \mathrm{L}$ of genomic DNA, $0.5 \mu \mathrm{M}$ DQ-forward primer, $0.5 \mu \mathrm{M}$ DQ-reverse primer, and 1X Thermo Scientific AbsoluteQPCR SYBR Green ROX Mix (Thermo Fisher Scientific Inc., Vilnius, Lithuania). For HGH control samples reactions were performed in $20 \mu \mathrm{L}$ volume containing $2 \mu \mathrm{L}$ of genomic DNA, $0.5 \mu \mathrm{M}$ HGH-specific forward primer, $0.5 \mu \mathrm{M}$ HGH-specific reverse primer, and $1 \mathrm{X}$ Thermo Scientific Absolute QPCR SYBR Green ROX Mix (Thermo Fisher Scientific Inc., Vilnius, Lithuania). A positive control or reference sample (DNA sample known to be positive for the searched alleles) was included in all reactions to standardize interpretations. Additionally, a known negative DNA sample (not containing the region of interest) and negative control (no DNA added to reaction) were run in set of reactions to test for contamination. PCR and melting curve conditions are detailed in Table 1. Amplified products were analyzed using a melting curve.

TABLE 1. qPCR conditions including temperature, time, and number of cycles, for $D Q A 1 * 05, D Q B 1 * 02, D Q A 1 * 03$ alleles and $\mathrm{HGH}$ gene

\begin{tabular}{lccc}
\hline Step & $\begin{array}{c}\text { Temperature } \\
\left({ }^{\circ} \mathrm{C}\right)\end{array}$ & Time & Cycles \\
\hline Initial denaturation & 95 & $10 \mathrm{~min}$. & 1
\end{tabular}

$\begin{array}{llll} & 95 & 15 \mathrm{sec} . & 32 \\ \text { Annealing and extension } & 60 & 60 \mathrm{sec} .\end{array}$

Melt curve - step 1

Melt curve - step $2 \quad 60 \quad 60 \mathrm{sec} . \quad 1$

Melt curve - step $3 \quad 60-95 *$

* Temperature increases from $60^{\circ} \mathrm{C}$ to $95^{\circ} \mathrm{C}$ by increments of $0.3^{\circ} \mathrm{C}$ with simultaneous SYBR Green I signal monitoring.

Since this was the first attempt to use this protocol with these alleles, we used a parallel PCR-SSP protocol as a reference method to validate our positive results. The conditions and reactions were performed using DQ-CD Typing Kit Plus (BioDiagene, Palermo, Italy) according to the manufacturer's recommendations.

\section{RESULTS}

Results obtained by qPCR technique were determined to be highly reliable with no discordant results when compared with those obtained using PCR-SSP; however, the latter technique did provide some additional details in terms of homozygosity and heterozygosity, which will be detailed shortly. Using both techniques, from a total of 329 samples, $187(56.8 \%)$ were determined positive for HLA predisposing alleles. With qPCR, these 187 positive samples could be subdivided into $114(61.0 \%)$ positive for a single allele, $68(36.3 \%)$ for two alleles, and only $5(2.7 \%)$ for three alleles (Table 2 ). The evidenced mean $T m$ for the three analyzed alleles were $80.12 \pm 0.1^{\circ} \mathrm{C}$ for $D Q A 1^{*} 05 ; 86.49 \pm 0.13^{\circ} \mathrm{C}$ for $D Q B 1^{*} 02$ and $80.69 \pm 0.11^{\circ} \mathrm{C}$ for $D Q A 1^{*} 03$, melting curves for each are 
shown in Figure 1. For the HGH gene, the evidenced mean Tm was $83.5^{\circ} \mathrm{C} \pm 0.1^{\circ} \mathrm{C}$. The most common combination of positive alleles was $D Q A 1^{*} 05$ and $D Q B 1^{*} 02$ (Table 2), which code for class II MHC DQ2 molecules. With PCR-SSP, these 187 could be further subdivided to inform whether a sample was heterozygous $(\mathrm{DQB} 1 * 02 / \mathrm{x} ; \mathrm{n}=70 ; 37.5 \%)$ or homozygous (DQB1*02/02 haplotype; $n=22 ; 11.7 \%$ ) for the $\beta$-chain of the DQ2 which allowed to differentiate between haplotypes in cis and trans (Table 2).

TABLE 2. Summary of the 187 samples that tested positive, with PCR-SSP and qPCR, for one or more of three analyzed HLA predisposing alleles: $D Q A 1 * 05$ (DQ2), DQB1*02 (DQ2), and DQA1*03 (DQ8). The number of individuals (and \% of total) determined to be positive at one or more alleles are reported

\begin{tabular}{|c|c|c|}
\hline \multirow{2}{*}{ Alleles } & \multicolumn{2}{|c|}{ Number $(\%)$} \\
\hline & PCR-SSP & qPCR \\
\hline $\begin{array}{l}D Q A 1 * 05 \\
D Q B 1 * 02 \\
D Q A 1 * 03\end{array}$ & $5(2.7)$ & $5(2.7)$ \\
\hline $\begin{array}{l}\text { DQA1 } * 05 \\
\text { DQB1*02/02 }\end{array}$ & $18(9.6)^{\wedge}$ & $58(310) \#$ \\
\hline $\begin{array}{l}\text { DQA } 1 * 05 \\
\text { DQB } 1 * 02 / \mathrm{x}\end{array}$ & $40(21.4)^{\ddagger}$ & $30(31.0)$ \\
\hline$D Q A 1 * 05$ & $43(23)$ & $43(23.0)^{\S}$ \\
\hline $\mathrm{DQB} 1 * 02 / 02$ & $4(2.1)^{\wedge}$ & $24(10028$ \\
\hline $\mathrm{DQB} 1 * 02 / \mathrm{x}$ & $30(16.1)^{\ddagger}$ & \\
\hline$D Q A 1 * 03$ & 37 (19.8) & $37(19.8)^{\S}$ \\
\hline $\begin{array}{l}D Q A 1 * 03 \\
D Q B 1 * 02\end{array}$ & $10(5.3)$ & $10(5.3)^{\#}$ \\
\hline Total & $187(56.8)$ & $187(56.8)$ \\
\hline
\end{tabular}

DQB1*02/02: homozygosity of the $\beta$-chain of the DQ2; DQB1*02/x: heterozygosity of the $\beta$-chain of the DQ2; ${ }^{\star}$ Samples that were heterozygous for DQB1*02 $(\Sigma 70)$; ^ ${ }^{\wedge}$ Samples that were homozygous for DQB1*02 ( $\Sigma 22)$. ${ }^{\S}$ Samples that tested positive for only one allele $(\Sigma$ 114); " Samples that tested positive for two alleles $\left(\sum 68\right)$

\section{DISCUSSION}

In light of the great need of cost-effective and specific assays for the determination of celiac associated HLA alleles (especially in high-risk populations), we successfully developed a qPCR technique that uses PCR-SSP primers. As we chose to use primers that were originally designed to be used with PCR-SSP method ${ }^{(7)}$, all qPCR results were confirmed using a reference method (DQ-CD TypingKitPlus). The qPCR-based typing system, despite its incapability to determine DQB1*02 allele homozygosis, proved to be highly reliable with no discordant results compared with the ones obtained with PCR-SSP. Determination of DQB1*02 homozygosis, although important when estimation of risk of having celiac disease is pursued, has a low relevance when the goal is to identify, inside a high risk population, which patients must be followed up, as was intended in this work.

Considering that qPCR procedures are faster, comprise fewer handling steps and are highly sensitive; we can affirm that this study managed to combine the simplicity of real-time PCR with the specificity of PCR-SSP. This makes it an excellent candidate when it comes to clinics, both in the detection of the genetic bases of the disease in a patient, for later familiar screenings to detect predisposition of developing the disease, and in the main role of HLA typing that lies in its high negative predictive value to exclude $\mathrm{CD}$ (close to $100 \%)^{(10)}$. Moreover, the fact of being a simple laboratory technique with few requirements, both in handling steps and equipments, can sometimes make the difference between finishing or not a scientific work for some scientist of developing countries who, like us, do not always have access to imported commercial kits or even having, the delay in arriving could interfere in the development of our work. One of the limitations of this study was not having analyzed the DQB1*03:02 allele, which is also associated with celiac disease. The reason for that was that the par of primers cited by Olerup et al. (1993), for this allele, also amplified DQB1*03:03 which is not related to celiac

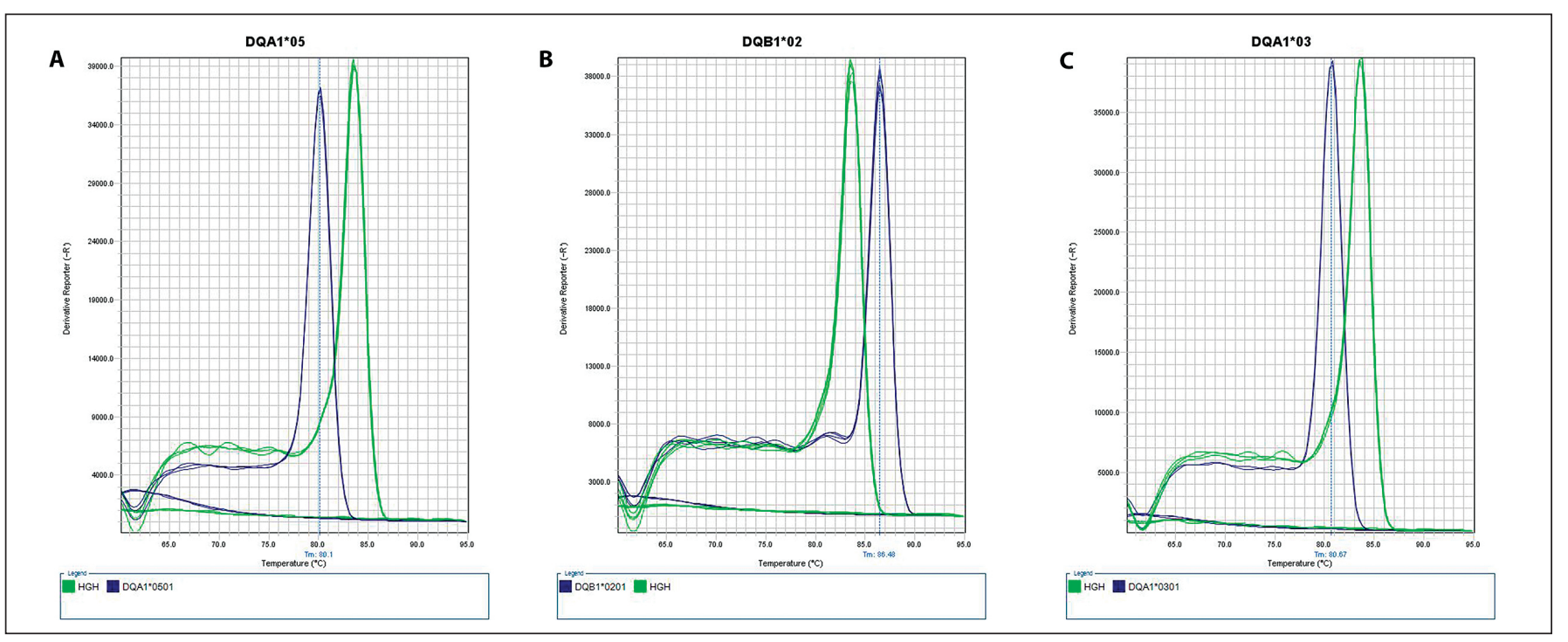

FIGURE 1. Melting curves of the analyzed alleles. A: DQA1*05; B: DQB1*02; C: DQA1*03 
disease, giving false positive results. However, in our laboratory routine, we obtained excellent results by using the DQB1*03:02 primers used by Profaizer et al. (2001), and reproducing the qPCR conditions cited by the author.

\section{ACKNOWLEDGMENTS}

We thank the "Coordenação de Aperfeiçoamento de Pessoal de nível Superior" (CAPES) and the "Fundação de Apoio a Pesquisa do Distrito Federal" (FAPDF) for their financial support.

\section{Authors' contributions}

Selleski $\mathrm{N}$ participated in the study analysis and drafted the manuscript. Almeida LM e Almeida FC were involved in study design and data analysis. Gandolfi L participated in recruitment, data collection and data analysis. Pratesi $\mathrm{R}$ conceived the study and contributed to data collection and statistical analysis. Nóbrega YKM helped with data analysis and supervised the study design and coordination. All authors read and approved the final manuscript.

Selleski N, Almeida LM, Almeida FC, Gandolfi L, Pratesi R, Nóbrega YKM. Simplificação da detecção dos alelos HLA-DQ predisponentes para doença celíaca pelo método de PCR em tempo real. Arq Gastroenterol. 2015,52(2):143-6.

RESUMO - Contexto - Doença celíaca é uma enteropatia autoimmune desencadeada pela ingestão de gluten em indivíduos geneticamente suscetíveis. Essa suscetibilidade genética está associada a dois conjuntos de alelos, $D Q A 1^{*} 05-D Q B 1^{*} 02$ e $D Q A 1^{*} 03-D Q B 1 * 03: 02$, que codificam moléculas MHC de classe II DQ2 e DQ8, respectivamente. Aproximadamente 90\%-95\% dos pacientes celíacos são HLA-DQ2 positivos, e metade dos restantes são HLA-DQ8 positivos. No diagnóstico da doença celíaca, a ausência desses alelos DQA e DQB específicos possui um elevado valor preditivo negativo. Objetivo - Nosso objetivo foi melhorar a detecção de alguns alelos predisponentes para doença celíaca, combinando a simplicidade e sensibilidade da técnica de PCR em tempo real (qPCR) e análise da curva de melting com a especificidade dos primers de sequência específica. Métodos - Primers de sequência específica para $D Q A 1 * 05(\mathrm{DQ} 2), D Q B 1 * 02(\mathrm{DQ} 2)$, e $D Q A 1 * 03$ (DQ8) foram usados para testar a presença de cada alelo em reações independentes. Primers para Hormônio de Crescimento Humano foram usados como controle interno. Em paralelo, foi usado um protocolo de PCRSSP como um método de referência para validar nossos resultados positivos. Resultados - Das 329 amostras testadas, 187 (56.8\%) foram positivas para os alelos HLA predisponentes, usando as duas técnicas. Essas 187 amostras positivas foram subdivididas em $114(61.0 \%)$ positivas para apenas um alelo, $68(36.3 \%)$ para dois alelos e apenas $5(2.7 \%)$ para os três alelos. Conclusão - Os resultados obtidos pela técnica de qPCR mostraram-se altamente confiáveis, sem resultados discordantes quando comparados àqueles obtidos pelo método PCR-SSP.

DESCRITORES - Doença celíaca. Antígenos HLA-DQ. Teste de histocompatibilidade. Reação em cadeia da polimerase em tempo real.

\section{REFERENCES}

1. Farrell RJ, Kelly CP. Celiac sprue. N Engl J Med. 2002;346(3):180-8.

2. Fasano A, Catassi C. Current approaches to diagnosis and treatment of celiac disease: an evolving spectrum. Gastroenterology. 2001;120(3):636-51.

3. Green PHR, Cellier C. Celiac disease. N Engl J Med. 2007;357(17):1731-43.

4. Karell K, Louka AS, Moodie SJ,Ascher H, Clot F, Greco L, et al. HLA types in celiac disease patients not carrying the DQA $1 * 05-\mathrm{DQB} 1 * 02$ (DQ2) heterodimer: results from the European Genetics Cluster on Celiac Disease. Human Immunology. 2003;64(4):469-77.

5. Louka AS, Sollid LM. HLA in celiac disease: Unravelling the complex genetics of a complex disorder. Tissue Antigens. 2003;61(2):105-17.
6. Megiorni F, Pizzuti A. HLA-DQA1 and HLA-DQB1 in Celiac disease predisposition: practical implications of the HLA molecular typing. J Biomed Sci. 2012;19:88.

7. Olerup O, Aldener A, Fogdell A. HLA-DQB1 and -DQA1 typing by PCR amplification with sequence-specific primers (PCR-SSP) in 2 hours. Tissue Antigens. 1993;41(3):119-34.

8. Profaizer T, Eckels D, Delgado JC. Celiac disease and HLA typing using real-time PCR with melting curve analysis. Tissue Antigens. 2011;78(1):31-7.

9. Sollid LM, Markussen G, Ek J, Gjerde H, Vartdal F, Thorsby E. Evidence for a primary association of celiac disease to a particular HLA-DQ alpha/beta heterodimer. J Exp Med. 1989;169(1):345-50.

10. Wolters VM, Wijmenga C. Genetic background of celiac disease and its clinical implications. Am J Gastroenterol. 2008;103(1):190-5. 